\title{
Analysis of Economic Empowerment of Coastal Communities Towards Prosperous Communities
}

\author{
Ratna Ekasari ${ }^{1}$, Donny Arif ${ }^{2}$, Wulan Purnamasari ${ }^{3}$, Nikma Yucha $^{4}$ \\ Faculty of Economics, Universitas Maarif Hasyim Latif, Jawa Timur, Indonesia ${ }^{1-4}$ \\ \{ratna ekasari@dosen.umaha.ac.id ${ }^{1}$, doni arif@dosen.umaha.ac.id ${ }^{2}$, \\ wulan purnamasari@dosen.umaha.ac.id $\left.{ }^{3} 2^{4} \underline{n i k m a @ d o s e n . u m a h a . a c . i d ~}^{4}\right\}$
}

\begin{abstract}
The coastal and coastal areas of East Java have quite diverse natural resource potential, including the possibility of capture fisheries, aquaculture, processing industries fish, agriculture, plantation, farm, and tour beach. Behind all the potential possessed by the coastal and coastal areas of East Java, has a fundamental problem, namely the welfare of the community.

This study aims to analyze the economic empowerment of coastal communities and analyze the welfare of coastal communities. This research was conducted using a qualitative research perspective with a case study method. This method is used because it examines a case or a particular phenomenon that exists in the community that is done in depth to study the background, circumstances, and interactions that occur.

The results of the study showed that to improve long-term welfare, the village community itself had to move and supported by the role of the government, village officials or related parties, it was very necessary to provide understanding, counseling and training and assistance in empowering villagers, by utilizing the existing potential to improve the village economy which has an impact on improving the welfare of the villagers.
\end{abstract}

Keywords: Economic Empowerment, Community Welfare.

\section{Introduction}

East Java residents who live in rural coastal areas have not been able to improve community welfare. If compared to the potential of natural resources in coastal areas with non-coastal areas, it is very unbalanced; coastal communities should be more prosperous compared to the facts that exist today[1]. Many factors must be resolved, one of which is economic empowerment which is still minimal when compared to non-coastal areas[2].

\section{Literature review}

\subsection{Economic Empowerment}

The concept of economic empowerment is the process of developing, empowering, empowering, strengthening the bargaining position of the lower classes of society towards suppressive forces in all sectors and sectors of life[3], [4]. Empowerment is the process of facilitating community members together on a common interest or affair that can collectively 
identify targets, gather resources, mobilize a campaign of action and therefore help rearrange strength in the community[5]-[7].

\subsection{Community Welfare}

Community welfare is overall human well-being (material, spiritual, and moral) by using efficient resources and equitable income distribution[8]-[10].

\section{Method}

Qualitative research requires the direct involvement of researchers in the data collection process so that the position of researchers as well as an instrument in research. In the qualitative research of researchers as human instruments and with techniques of participant observation data collection and in-depth interview[11].

Case study research method because this study examines a particular case or phenomenon that exists in the community that is done in depth to study the background, circumstances, and interactions that occur. Case studies are carried out on a unified system that can be a program, activity, event, or group of individuals who are in certain conditions or conditions[12].

\section{Results and discussion}

From the data obtained from each village the object of research, related to village economic empowerment, can be presented as follows:

a. Banyusangka Village

Banyusangka Village establishes village programs that are related to village economic empowerment, among others :

1) fostering villagers through various counseling to improve the ability of villagers to cultivate marine products so that they have added value and value sell

2) Bridging the trade in crops/sea between villagers and partner companies, for example, fish processing companies in Gresik

From these conditions and natural potential, the welfare of the villagers is quite achievable, but the development is not too significant because the villagers are apathetic about their participation in village development. The desire to provide added value by further processing sea products, they are also reluctant to do, because of the narrow perspective and in the short term to be able to immediately enjoy the results of the sale of marine resources that they sell.

\subsection{Sepulu Village}

Sepulu Village establishes village programs related to village economic empowerment, including:

1) Prepare to become a sea tourism village, to provide added value to the village treasury and empower villagers to get additional input

2) Developing a shipbuilding industry, in order to be able to compete on a scale national

3) training for mothers to be able to process fish so that it has added value. Besides counseling about fisheries and agriculture.

From these conditions and natural potential, the welfare of the villagers is sufficiently achieved, but the development is not too significant because the desire to provide added value 
by further processing sea products, they are also reluctant to do, because of the narrow perspective and the immediate results the sale of marine resources they sell.

\subsection{Pesisir Village}

Pesisir Village establishes village programs related to village economic empowerment, including:

1) $\mathrm{M}$ processing sea products to have added value and selling value, including processing shrimp and fish into ready-to-serve food. Processing seafood in the form of shellfish as a craft hand.

2) Produce processed foods in the form of salted eggs, shrimp paste, and Abon Catfish.

3) Producing handicraft products namely border and weaving results in hand

4) training for mothers for fish processing, in addition to education in fisheries and agriculture,

From these conditions and natural potential, the welfare of the villagers is quite achievable, but the development is not too significant because the village community has not done economic empowerment in a long time and lack of infrastructure owned by the village community.

\subsection{Banjarsari Village}

Banjarsari Village establishes village programs related to village economic empowerment, including:

1) Empowering villagers to cultivate catfish livestock, given the very market demand well.

2) Produce processed foods in the form of salted eggs, shrimp paste, and Abon Catfish.

3) Produce craft products hand

From these conditions and natural potential, the welfare of the villagers is quite achievable, but the development is not too significant because the village community has not done economic empowerment in a long time and lack of infrastructure owned by the village community.

b. Pesisir Village

Pesisir Village establishes village programs related to village economic empowerment, including:

(1) The empowerment of TPI owned by the village to develop more big

(2) Produce processed foods in the form of salted fish, Krupuk Ikan, and Abon Fish

(3) To empower the villagers to increase home production in the form of Fish, Lopis and Sticky Sticks Mix

From these conditions and natural potential, the welfare of the villagers is quite achievable, but the development is not too significant because the village community has not done economic empowerment in a long time and lack of infrastructure owned by the village community.

\subsection{Bletok Village}

Blethok Village establishes village programs related to village economic empowerment, including: 
Empowering villagers to process seafood to have added value, namely fish and shrimp cultivation

developing handicrafts for shellfish processing, for crafting photo frames and accessories, which were then shipped out of the area including Bali and Jogjakarta

From the field conditions, the relevant parties should pay special attention and handling, by involving and empowering the villagers through counseling and training by the potential available and produced by the village. With the empowerment of villagers in a concept similar to SMEs or home industries, it will be empowered and effective, also providing the skills of residents of coastal villages to provide added value to their natural products, which can be sold through and cooperating with field government agencies. Micro, small and medium enterprises. Community welfare in its broadest sense includes a variety of actions taken by humans as members of the community to achieve a better standard of living. A better standard of living is not only measured economically or physically but includes social, mental and spiritual aspects. Promoting the transition of the stages of welfare, interference or development support from both the public and private sectors is very necessary.

\section{Conclusion}

From the condition and potential of the natural causes, the welfare of the villagers is quite achievable, but its development is not too significant because the village community has not done economic empowerment in a long time and lack of infrastructure owned by the village community

\section{References}

[1] M. Rahim, M. Tahir, and W. A. Rumbia, "Model Pemberdayaan Masyarakat di Wilayah Pesisir dalam Menanggulangi Kemiskinan di Kabupaten Buton, Sulawesi Tenggara," The Winners, vol. 15, no. 1, pp. 23-33, 2014.

[2] S. Widodo, "Strategi nafkah berkelanjutan bagi rumah tangga miskin di daerah pesisir," Hubs-Asia, vol. 10, no. 1, 2011.

[3] R. Scheyvens, "Ecotourism and the empowerment of local communities," Tour. Manag., vol. 20, no. 2, pp. 245-249, 1999.

[4] P. A. Wilson, "Empowerment: Community economic development from the inside out," Urban Stud., vol. 33, no. 4-5, pp. 617-630, 1996.

[5] N. Page and C. E. Czuba, "Empowerment: What is it," J. Ext., vol. 37, no. 5, pp. 1-5, 1999.

[6] J. Rowlands, "Empowerment examined," Dev. Pract., vol. 5, no. 2, pp. 101-107, 1995.

[7] T. Ma'sum and M. B. N. Wajdi, "Pengembangan Kemandirian Pesantren Melalui Program Santripreneur,” ENGAGEMENT, vol. 2, no. 2, pp. 221-232, 2018.

[8] R. Costanza et al., "Quality of life: An approach integrating opportunities, human needs, and subjective well-being," Ecol. Econ., vol. 61, no. 2-3, pp. 267-276, 2007.

[9] A. Offer, "Economic Welfare Measurements and Human Well-Being.," 2000.

[10] B. Jordan, Welfare and well-being: Social value in public policy. Policy Press, 2008.

[11] J. W. Creswell and J. D. Creswell, Research design: Qualitative, quantitative, and mixed methods approaches. Sage publications, 2017.

[12] P. Sugiyono, "Metode Penelitian Kuantitatif, Kualitatif, dan R\&D," Metod. Penelit. Kuantitatif, Kualitatif, dan R\&D. Bandung CV Alf., 2010. 